\title{
EFFECT OF HOUSING DENSITY, DURATION OF FATTENING AND INITIAL BODY MASS OF ONE DAY OLD CHICKENS ON PRODUCTION OF BROILER MEAT OF COBB HYBRID ${ }^{1}$
}

\author{
S. Mitrović, Zdenka Škrbić, Snežana Bogosavljević Bošković, Đ. Ostojić, V. Đermanović ${ }^{2}$
}

Content: Objective of the research was to investigate the effect of housing density (number of birds per $\mathrm{m}^{2}$ of floor surface), duration of fattening and mass of one day old chickens on basic production parameters in intensive production of broiler meat. Investigation included 30 fattening cycles of broiler chickens of heavy Cobb 500 hybrid. Mentioned fattening cycles were realized in period from 1999 to 2004 on private poultry farm in the vicinity of Brčko-Lončari (Republika Srpska). Depending on the fattening cycle, the least birds per $\mathrm{m}^{2}$ of floor surface was 12,31 and the greatest 17,16 birds of both sexes. Fattening lasted 39 to 46 days and average mass of one day old chickens varied between 38 and 46 grams. Housing density during fattening had significant effect on daily gain $\left(r_{p}=0,436^{x}\right)$ and value of production index $\left(r_{p}=0,442^{x}\right)$, but signifying medium correlation. Duration of fattening and mass of one day old chickens, in regard to monitored production parameters, have demonstrated mainly weak correlation except the effect of mass of one day old chickens on feed conversion where negative coefficient of phenotype correlation $\left(r_{p}=-0,382^{x}\right)$ was established and correlation determined as weak.

Key words: housing density, correlation, mass of one day old chickens, duration of fattening

\section{Introduction}

Success in intensive fattening of broiler chickens, beside the genotype, nutrition, preventive health care, etc. considerably depends on other factors such as housing density, duration of fattening and initial mass of one day old chickens. Some researchers find that of all environment factors housing density is the first one influencing the less rapid growth of chickens (Shanawany, 1988). Rearing of great number of broiler chickens is connected with high production costs, but, in some cases, increase of number of birds per $\mathrm{m}^{2}$ of floor space is directed towards optimization of production without further investment in new production buildings (Proudfoot et al., 1979). Higher housing density enables production of greater meat quantities at the level of $1250 \mathrm{~g}$ per additional bird in box (Edriss et al., 2003), however, the live body mass of chickens at slaughter decreases which is not ideal situation from commercial aspect (Mendes et al., 2004). In order to achieve economical efficiency of production the issue of duration of fattening is repeatedly discussed (Mitrović, 2004) as well as the effect of initial mass of one day old chickens (Mašić, 2001, Tolimir, 2003) on production performance of broilers.

Objective of the paper was to investigate in more detail the effect of mentioned factors on major production parameters (daily gain, feed conversion, mortality and value of production index) in intensive fattening of broiler chickens of Cobb 500 hybrid.

\section{Material and methods}

On analyzed private household/farm in period 1999 to 2004 total of 30 fattening cycles of broiler chickens of heavy Cobb 500 hybrid were realized. All chickens were fattened in the same chicken coop of total production floor surface of $693 \mathrm{~m}^{2}$ (with manipulation sector of $743 \mathrm{~m}^{2}$.

In case of fattening cycle with the lowest housing density $\left(12,31 \mathrm{birds} / \mathrm{m}^{2)}\right.$ total of $8530 \mathrm{birds}$ were housed, and in cycle with the highest housing density $\left(17,85 \mathrm{birds} / \mathrm{m}^{2}\right) 12190$ one day old chickens of both sexes were housed. Depending on the fattening cycle duration of fattening was from 39 to 46 days, and average initial mass of one day old broiler chickens varied between 38 and 46 grams.

During fattening, with minimal modifications, mainly fattening technology and nutrition program recommended by the producer of specific hybrid were used. Chickens were fattened in chicken coop constructed of bricks with windows and ceiling, on floor with deep litter.

For each fattening cycle during investigation period following parameters were determined: housing

1 Original scientific paper - supported by the Ministry of Science and Environment Protection, Project no. TR6885B - Originalni naučni rad je finansiran od strane Ministarstva za nauku i zaštitu životne sredine Projektom broj: TR6885B

2 Dr Sreten Mitrović, full professor, Faculty of Agriculture, Belgrade-Zemun, mr Zdenka Škrbić, research assistant, Institute for Animal Husbandry, Belgrade-Zemun, dr Snežana Bogosavljević Bošković, associate professor, Agronomical faculty, Čačak, Grad.eng. Đorđe Ostojić, Brčko-Lončari (Republika Srpska), Grad eng. Vladan Đermanović, Institute PKB "Agroekonomik", Belgrade 
density, mass of one day old chickens, feed conversion and mortality. It should be expected that fattening of broilers is more profitable (economical) if the value of production index is higher since most significant production parameters/indicators of fattening of broiler chickens are incorporated in the index (duration of fattening, mortality, feed conversion and final body mass).

Also, obtained data was processed using correlation analysis, that is between majority of production (fattening) parameters the strength of correlation was determined. Correlation analysis didn't include, justifiably so, the final body mass of chickens since duration of fattening was different. Therefore, correlation coefficients between housing density, duration of fattening, initial mass of one day old chickens (on one side) and average daily gain (on the other side) were calculated.

\section{Results and discussion}

Major production-fattening parameters of broiler chickens of Cobb 500 hybrid fattened in period from 1999 to 2004 in 30 fattening cycles are presented in table 1.

Data presented in table 1 indicate that housing density according to fattening cycles varied from 12,31 to 17,85 birds per $\mathrm{m}^{2}$ of floor surface, duration of fattening from 39 to 46 days and mass of one day old chickens from 38 to 46 grams. Mass of fattened broiler chickens varied from 2,068 to $2,550 \mathrm{~kg}$. The highest average daily gain was $59,32 \mathrm{~g}$ and the lowest $48,83 \mathrm{~g}$. Feed conversion was favourable and only in two fattening cycles consumption of food per $1 \mathrm{~kg}$ of gain was over $2 \mathrm{~kg}$, more precisely $2,03 \mathrm{~kg}$. Mortality of broiler chickens in relation to number of housed birds varied from 1,79 to $6,13 \%$. Value of production index depended on the majority of analyzed production parameters and was established between 249,07 and 307,52. Value of production index could greatly contribute to defining the optimal housing density and duration of fattening for intensive fattening of broiler chickens of Cobb 500 hybrid.

Table 1. Realized production-fattening results of broiler chickens of Cobb 500 hybrid

\begin{tabular}{|c|c|c|c|c|c|c|c|c|}
\hline $\mathrm{N}^{0}$ & $\begin{array}{c}\text { Birds per } \\
\mathrm{m}^{2}\end{array}$ & $\begin{array}{l}\text { Days of } \\
\text { fattening }\end{array}$ & Initial mass, $\mathrm{g}$ & Final mass, $\mathrm{kg}$ & Daily gain, $\mathrm{g}$ & Feed conversion, $\mathrm{kg}$ & Mortality, \% & P.I. \\
\hline 1. & 12,31 & 39 & 40,00 & 2,100 & 52,82 & 1,94 & 5,03 & 263,58 \\
\hline 2. & 12,49 & 42 & 38,00 & 2,089 & 48,83 & 1,85 & 3,06 & 260,62 \\
\hline 3. & 12,50 & 40 & 43,00 & 2,155 & 52,80 & 1,77 & 5,99 & 286,56 \\
\hline 4. & 12,92 & 42 & 46,00 & 2,103 & 50,23 & 1,79 & 5,38 & 264,64 \\
\hline 5. & 12,98 & 42 & 42,00 & 2,223 & 52,05 & 2,03 & 3,05 & 253,34 \\
\hline 6. & 13,09 & 43 & 43,50 & 2,149 & 48,97 & 1,88 & 5,15 & 252,14 \\
\hline 7. & 13,41 & 46 & 42,00 & 2,320 & 49,52 & 1,88 & 3,95 & 257,67 \\
\hline 8. & 13,42 & 39 & 38,00 & 2,137 & 55,09 & 2,03 & 5,01 & 256,39 \\
\hline 9. & 13,92 & 39 & 43,00 & 2,068 & 51,92 & 1,93 & 1,79 & 269,82 \\
\hline 10. & 14,04 & 39 & 44,00 & 2,139 & 53,72 & 1,85 & 2,85 & 249,07 \\
\hline 11. & 14,28 & 41 & 43,00 & 2,361 & 56,54 & 1,86 & 4,20 & 296,59 \\
\hline 12. & 14,52 & 42 & 42,00 & 2,250 & 52,57 & 1,94 & 3,05 & 267,70 \\
\hline 13. & 14,58 & 43 & 42,50 & 2,566 & 58,69 & 1,99 & 4,40 & 286,67 \\
\hline 14. & 15,26 & 42 & 41,00 & 2,324 & 54,36 & 1,91 & 3,83 & 278,60 \\
\hline 15. & 15,66 & 42 & 40,00 & 2,328 & 54,48 & 1,93 & 2,08 & 281,22 \\
\hline 16. & 15,70 & 45 & 44,20 & 2,637 & 57,66 & 1,89 & 3,19 & 300,16 \\
\hline 17. & 15,75 & 46 & 44,00 & 2,373 & 50,63 & 1,85 & 2,33 & 272,35 \\
\hline 18. & 15,81 & 39 & 41,00 & 2,176 & 54,74 & 1,79 & 2,69 & 303,32 \\
\hline 19. & 15,90 & 40 & 42,00 & 2,267 & 55,62 & 1,78 & 2,59 & 295,38 \\
\hline 20. & 15,95 & 43 & 40,00 & 2,256 & 52,83 & 1,78 & 2,09 & 288,58 \\
\hline 21. & 16,11 & 42 & 41,00 & 2,330 & 54,50 & 1,95 & 3,84 & 273,56 \\
\hline 22. & 16,50 & 42 & 42,20 & 2,350 & 54,95 & 1,91 & 3,13 & 283,76 \\
\hline 23. & 16,66 & 43 & 42,00 & 2,550 & 58,32 & 1,97 & 3,51 & 290,46 \\
\hline 24. & 16,70 & 42 & 41,50 & 2,424 & 56,73 & 1,91 & 3,50 & 291,59 \\
\hline 25. & 16,85 & 41 & 42,20 & 2,384 & 57,12 & 1,88 & 6,00 & 290,73 \\
\hline 26. & 16,91 & 39 & 43,50 & 2,300 & 59,32 & 1,86 & 3,01 & 307,52 \\
\hline 27. & 17,42 & 43 & 42,50 & 2,250 & 51,34 & 1,91 & 3,87 & 263,35 \\
\hline 28. & 17,55 & 42 & 43,00 & 2,255 & 52,67 & 1,90 & 5,38 & 267,38 \\
\hline 29. & 17,74 & 41 & 42,50 & 2,250 & 53,84 & 1,89 & 3,06 & 281,46 \\
\hline 30. & 17,85 & 41 & 41,50 & 2,258 & 54,06 & 1,95 & 6,13 & 265,11 \\
\hline Pros. & 15,16 & 41,67 & 42,04 & 2,278 & 53,90 & 1,89 & 3,77 & 278,33 \\
\hline
\end{tabular}


Compared to results obtained by Arsenijević et al. (2001), Đermanović and Mitrović (2004), Bogosavljević Bošković et al. (1996) broiler chickens of Cobb 500 hybrid were in majority of the monitored production (fattening) traits demonstrated more or less better results. Beside that, it should be pointed out that value of production index (table 1) was on high level, especially in case of fattening which lasted 39 days and housing density between 15 and $17 \mathrm{birds} / \mathrm{m}^{2}$ of floor space. Calculated average value of production index for all 30 fattening cycles $(278,33)$ was higher than value obtained by other authors who investigated the same issues.

In order to determine the effect of housing density, duration of fattening and mass of one day old chickens on fattening results of broiler chickens correlation analysis was used, in other words, phenotype coefficients were calculated between monitored parameters (table 2).

Table 2. Correlation between monitored parameters in fattening of Cobb 500 broiler chickens

\begin{tabular}{|c|c|c|c|}
\hline $\begin{array}{c}\text { Traits } \\
\text { Comparisons } \\
\end{array}$ & $r_{(p)}$ & $t_{\text {exp. }}$ & Meaning of correlation \\
\hline G.N. - T.T. & $0,107^{\mathrm{ns}}$ & 0,569 & very weak \\
\hline G.N. - D.P. & $0,436^{\mathrm{x}}$ & 2,563 & medium \\
\hline G.N. - K.H. & $0,025^{\mathrm{ns}}$ & 0,134 & none \\
\hline G.N. - Mor. & $-0,118^{\mathrm{ns}}$ & 0,626 & very weak \\
\hline G.N. - P.I. & $0,442^{x}$ & 2,607 & medium \\
\hline T.T. - D.P. & $-0,244^{\mathrm{ns}}$ & 1,329 & very weak \\
\hline T.T. - K.H. & $0,058^{\mathrm{ns}}$ & 0,305 & none \\
\hline T.T. - Mor. & $-0,133^{\mathrm{ns}}$ & 0,711 & very weak \\
\hline T.T. - P.I. & $-0,081^{\mathrm{ns}}$ & 0,432 & none \\
\hline M.P. - D.P. & $0,021^{\mathrm{ns}}$ & 0,110 & none \\
\hline M.P. - K.H. & $-0,382^{x}$ & 2,188 & weak \\
\hline M.P. - Mor. & $0,242^{\mathrm{ns}}$ & 1,318 & very weak \\
\hline M.P. - P.I. & $0,091^{\mathrm{ns}}$ & 0,486 & none \\
\hline
\end{tabular}

*G.N./housing density; T.T./duration of fattening; D.P/daily gain; Mor./mortality; P.I./production index; M.P./mass of chickens; K.H./feed conversion

$\mathrm{t}_{\text {tab. }}$ for $5 \%=2,00 \& \mathrm{t}_{\text {tab. }}$ for $1 \%=2,66$

Data presented in table 2 show that housing density had statistically significant effect $(p<0,05)$ on daily gain and value of production index, but signifying medium correlation. Body mass of broilers and feed conversion were not influenced significantly by the housing density which is in accordance with results obtained by Imaeda (2000), whereas El-Deek et al. (2004) with similar results concluded that there were significant differences but only in the last phase of fattening. Contrary to this, Edriss et al., (2003) established significant effect of the housing density on body mass in all fattening weeks. Housing density had no statistically significant effect on consumption of food, duration of fattening and mortality where negative correlation coefficients were determined $\left(\mathrm{r}_{\mathrm{p}}=0,118\right)$. With increase of housing density mortality of broiler chickens decreased slightly probably due to improvement of the environment conditions in the chicken coop, primarily because of the maintaining of optimal temperature in the chicken coop.

Data presented in table 2 shoe that duration of fattening had no statistical significant effect on monitored parameters, however negative correlation coefficients with daily gain $\left(r_{p}=-0,244\right)$, mortality $\left(r_{p}=-\right.$ $0,133)$ and value of production index $\left(r_{p}=-0,081\right)$ were determined. Prolonging of fattening reduced the daily gain which indicated that fattening of broiler chickens, according to presented data, should not last longer than 41 days, for Cobb 500 hybrid from 39 to 41 days. Similar results were obtained by Mitrović et al. (2004).

Initial body mass of one day old chickens had no statistically significant effect on daily gain, mortality and value of production index, but negative correlation coefficient between mass of chickens and feed conversion was established $\left(r_{p}=0,382^{x}\right)$ signifying weak correlation. Between initial mass of one day old chickens and average daily gain correlation coefficient was 0,021 without statistical confirmation. Obtained data re in certain way contrary to results obtained by Tolimir et al. (2003) who obtained statistically very significant correlation coefficients between initial and final body mass, but signifying very weak correlation. Mašić et al. (2001) concluded that difference of $1 \mathrm{~g}$ in mass of one day old chicken corresponds to difference of approx. 14 to $24 \mathrm{~g}$ in mass of broiler in the age of 6 weeks and that the lightest as well as the heaviest one day old chickens give final masses which are from the practical and production aspect acceptable. 


\title{
Conclusion
}

Based on results of five year research it can be concluded that housing density of broilers in fattening cycles had considerable effect on daily gain $\left(r_{p}=0,436^{x}\right)$ and value of production index $\left(r_{p}=0,442^{x}\right)$, signifying medium correlation. Duration of fattening and mass of one day old chickens had no statistically significant effect on monitored production parameters, except effect of initial mass of one day old chickens on feed conversion where negative phenotype correlation coefficient $\left(r=-0,382^{x}\right)$ was determined and correlation was weak.

In general, it can be concluded that broiler chickens of Cobb 500 hybrid are best fattened in following conditions: housing density of 15 to $17 \mathrm{birds} / \mathrm{m}^{2}$ of floor surface, duration of fattening from 39 to 41 days and average mass of one day old chickens of approx. $42 \mathrm{~g}$.

\section{UTICAJ GUSTINE NASELJENOSTI, TRAJANJA TOVA I POČETNE MASE JEDNODNEVNIH PILIĆA NA PROIZVODNJU BROJLERSKOG MESA HIBRIDA COBB}

\author{
S. Mitrović, Zdenka Škrbić, Snežana Bogosavljević Bošković, Đ. Ostojić, V. Đermanović
}

\section{Rezime}

Cilj istraživanja bio je ispitivanje uticaja gustine naseljenosti, trajanja tova i mase jednodnevnih pilića na osnovne proizvodne pokazatelje pri intenzivnoj proizvodnji brojlerskih pilića Cobb 500 na jednoj privatnoj farmi u okolini Brčkog-Lončari (Republika Srpska). Na pomenutoj farmi, u periodu od 1999. do 2004. godine utovljeno je 30 turnusa brojlerskih pilića. Gustina naseljenosti brojlerskih pilića po turnusima je bila različita i kretala se od 12,31 do 17,16 grla $/ \mathrm{m}^{2}$ podne površine. U zavisnosti od turnusa, tov je trajao 39 do 46 dana, a prosečna masa jednodnevnih pilića 38 do 46 grama.

Gustina naseljenosti po turnusima je značajno uticala na dnevni prirast $\left(r_{p}=0,436^{x}\right)$ i vrednost proizvodnog indeksa $\left(r_{p}=0,442^{x}\right)$, ali označavajući srednju korelacionu povezanost. Trajanje tova i masa jednodnevnih pilića nisu statistički značajno uticali na praćene proizvodne pokazatelje, osim uticaja početne mase jednodnevnih pilića na konverziju hrane gde je utvrđen negativni koeficijent fenotipske korelacije $(r=$ $\left.0,382^{x}\right)$ i jačina povezanosti je bila slaba.

Može se konstatovati da su brojlerski pilići hibrida Cobb 500 najbolje proizvodne rezultate ostvarili pri gustini naseljenosti od 15 do $17 \mathrm{grla} / \mathrm{m}^{2}$ podne površine, trajanju tova od 39 do 41 dan i prosečnoj masi jednodnevnih pilića od 42 grama.

\section{Literatura}

1. ARSENIJEVIĆ Ž., PAVLOVSKI Z., LUKIĆ M. (2001): Uticaj genotipa na proizvodne i klanične osobine tovnih pilića. Živinarstvo, 11, 241-244.

2. BOGOSAVLJEVIĆ BOŠKOVIĆ S., GAJIĆ I., MITROVIĆ S. (1996): Uticaj sistema gajenja na proizvodne osobine brojlerskih pilića. Nauka u živinarstvu, 1-2, 27-32.

3. ĐERMANOVIĆ V., MITROVIĆ S. (2004): Prikaz pojedinih osobina Arbor Acres hibrida u tovu brojlerskih pilića. Zbornik naučnih radova "Agroekonomik", Beograd, vol. 2, 69-73,

4. EDRISS M.A., DAVOODVANDI S., POURREZA J. (2003): The Effects of stock density on the prediction of performance and carcass traits in broiler chickens. Proceedings XVI ${ }^{\text {th }}$ European Symposium on the Quality of Poultry Meat, France 2003., 695-700.

5. EL-DEEK A.A., AL-HARTHI M.A. (2004): Responses of Modern Broiler Chicks to Stocking Density, Green Tea, Commercial Multi Enzymes and Their Interactions on Productive Performance, Carcass Characteristics, Liver Composition and Plasma Constituents. International Journal of Poultry Science 3(10): 635-645.

6. IMAEDA N. (2000): Influence of the stocking density and rearing season on incidence of sudden death syndrome in broiler chickens. Poultry Science Vol. 79, 201-204. 
7. MAŠIĆ B., KOLJAJIĆ V., TOLIMIR N., BRKIĆ N., ANOKIĆ N. (2001): Uticaj početnih na završne telesne mase tovnih pilića. Agroznanje, vol. 2, 4, 66-73.

8. MENDES A.A., GARCIA R.G., IMEIDA I.C.L.A., MOREIRA J. (2004): Effect of stocking densities and season on performance, environmental and thermoregulatory parameters and carcass yield of broiler chickens. XXII World's Poultry Congress, Turkey 2004, Book of abstracts, 417 (full text electrically published in Participant List \& Full text CD)

9. MITROVIĆ S., OSTOJIĆ Đ., ĐERMANOVIĆ V. (2004): Uticaj trajanja tova na proizvodna svojstva brojlerskih pilića različitih genotipova. Živinarstvo, 11, 7-11.

10. PROUDFOOT F.G., HULAN H.W. (1979): The effect of four stocking densities on broiler carcass grade, the incidence of breast blisters and other performance traits. Poultry Science, Vol. 58, 791-795.

11. SHANAWANY M.M. (1988): Broiler performance under high stocking densities. British Poultry Science, Vol. 29, 29-43.

12. TOLIMIR N., MAŠIĆ B., KOLJAJIĆ V., BRKIĆ N., ANOKIĆ N., MALETIĆ R. (2003): Uticaj početne mase jednodnevnih pilića na telesnu masu u toku i na kraju tova. Živinarstvo, 5, 11-14. 